"Predictors of efficiency in municipal waste management in Tshwane municipalities, South Africa"

AUTHORS Zeleke Worku (Dttps://orcid.org/0000-0002-8808-3052

ARTICLE INFO

Zeleke Worku (2016). Predictors of efficiency in municipal waste management in Tshwane municipalities, South Africa. Environmental Economics, 7(3), 45-51. doi:10.21511/ee.07(3).2016.05

DOI $\quad$ http://dx.doi.org/10.21511/ee.07(3).2016.05

RELEASED ON Friday, 21 October 2016

JOURNAL "Environmental Economics"

FOUNDER LLC "Consulting Publishing Company "Business Perspectives"

$\begin{array}{ccc}0 & b & 0 \\ \text { NUMBER OF REFERENCES } & \text { NUMBER OF FIGURES } & \text { NUMBER OF TABLES } \\ \mathbf{0} & \mathbf{0} & \mathbf{0}\end{array}$

(c) The author(s) 2022. This publication is an open access article. 


\title{
Predictors of efficiency in municipal waste management in Tshwane municipalities, South Africa
}

\begin{abstract}
A survey was conducted in local municipalities in the Tshwane region of Gauteng Province in South Africa in order to assess and evaluate the efficiency with which municipal waste is collected, disposed of, processed and recycled by local municipalities in Tshwane based on data gathered from 1,035 businesses. Efficiency in waste management was assessed by using a structural time-based model designed for evaluating efficiency as a function of the length of time required to manage and process municipal waste. Adherence to municipal bylaws and procedures recommended for solid waste management by businesses by the City of Tshwane was graded based on ISO 14000 and ISO 14031 standards and guidelines. The study found that efficiency in waste management was adversely influenced by lack of adherence to municipal bylaws and regulations, wrong perception on the benefits of proper waste management, and failure to provide customers with waste disposal bins, in a decreasing order of importance.
\end{abstract}

Keywords: Tshwane municipalities, waste management, efficiency, logit analysis.

JEL Classification: Q53, C25.

\section{Introduction}

The annual report issued by the City of Tshwane (2015) for the financial year 2013/2014 shows that about $1,734,295$ tons of solid waste is collected each year from businesses operating in the city. The solid waste produced by businesses in the city includes trash or garbage such as wood, product packaging, empty bottles, used tyres and car parts, and cans, garden refuse, furniture, clothing, leftover food, newspapers, wires, grease, appliances, paint, pieces of metal, broken containers, sheet metal, used medicine, and toxic compounds. Studies conducted by Snyman \& Vorster (2011), Worku, Snyman \& Muchie (2014), Marivate (2014) and Khale (2015) indicate that the efficiency with which municipal solid waste produced by businesses that operate in Tshwane local municipalities is inadequate by local and international standards. Studies conducted by Seeletse (2012), Worku, Snyman \& Muchie (2014) and Khale (2015) have pointed out that failure in the enforcement of municipal bylaws on municipal solid waste generated by small, micro and medium-sized enterprises in the central business district of Pretoria is a key obstacle to cleanliness and environmental sanitation in and around Pretoria. According to Worku, Snyman \& Muchie (2014), it is not efficient and economical to utilize traditional methods of municipal solid waste management for managing and processing the massive amount of waste that is generated on a daily basis by businesses that operate in the various local municipalities in Tshwane. The authors have proposed a framework that could be used for ensuring efficiency in municipal solid waste management in Tshwane. Studies by Marivate

(C) Zeleke Worku, 2016.

Zeleke Worku, Ph.D., Professor, Business School, Tshwane University of Technology (TUT), South Africa.
(2014) and Worku (2015) have shown that the provision of efficient municipal services to businesses that operate in and around Tshwane has a direct benefit for ensuring sustained profitability in start-up businesses. The study has the potential for identifying and quantifying predictors of efficiency in the management of waste generated by businesses in the central business district of Tshwane.

\section{Background of study}

The creation of an economically enabling and environmentally friendly working environment for start-up business enterprises is a key mandate of the South African Small Enterprise Development Agency (2014) and that of the South African Chamber of Commerce and Industry (2016). The overall aim of the study was to identify, quantify, assess and evaluate key predictors of efficiency in the management of municipal solid waste in Tshwane. A review of the literature shows that sustained growth and development in newly established businesses is often stifled by obstacles such as unnecessary administrative bureaucracy (Shree \& Urban, 2012), red tape (Henrekson, 2014), lack of good governance (Edoho, 2015), lack of infrastructural capacity required for the efficient management and processing of solid waste (Worku, 2013), lack of socioeconomic incentives to stakeholders relevant to the waste management chain (Worku, 2015), failure to adequately utilize modern waste management and processing technology (Worku, Snyman \& Muchie, 2014), failure to vigorously enforce municipal bylaws (Worku, 2013), and the absence of an integrated waste management system in Tshwane, as is recommended by the United States Environmental Protection Agency (2015) for developing nations of the world. 


\section{Literature review}

According to Statistics South Africa (2015), the Tshwane region is home to more than 3.2 million inhabitants and thousands of actively registered small, micro and medium-sized business enterprises. Almost all business enterprises generate large volumes of municipal solid waste. The waste generated by businesses is not managed efficiently due to the utilization of obsolete technological methods of waste management (Bernstad, Jansen \& Aspegren, 2012), failure to enforce municipal bylaws, and failure to allow the private sector to take part in the municipal solid waste management business (Worku, 2013). Nearly half of all newly established business enterprises that operate in the various geographical zones of Tshwane fail before operating for three years due to obstacles related to business license application, tax assessment, lack of entrepreneurial skills, and failure to raise loans (Asah, Fatoki \& Rungani, 2015). According to Brownson (2014) and Seeletse (2012), ensuring efficient municipal services on municipal solid waste management is a key aspect of promoting sustained growth and development in newly established businesses. The authors have pointed out that the efficient management of municipal solid waste can be adequately ensured by utilizing a combination of modern technological methods of waste management, and by implementing a comprehensive monitoring and evaluation programe. Between 1994 and 2014, the City of Tshwane (2015) has received qualified audit reports from the South African Auditor-General due to failure to provide efficient municipal services in areas related to municipal solid waste. According to the annual report issued by the South African National Department of Environmental Affairs (2015) for the financial year 2013/2014, all major South African cities including the City of Tshwane must aspire to provide world-class environmental, sanitary and municipal waste management services as a means of promoting overall economic growth and development. As such, drawing valuable lessons from the world's cleanest cities such as Singapore, London and New York is strategically beneficial for the City of Tshwane.

The City of Tshwane provides municipal services such as the removal and disposal of all types of waste, the assessment of municipal rates, health and sanitary services, housing services, infrastructural and environmental maintenance and repairs, safety and security, lighting, water and lights, traffic services, and the like to over 3.2 million people who live and work in Pretoria. The study conducted by Wagland, Veltre and Longhurst (2012) has identified practical and highly efficient methods of municipal solid waste management that could be utilized by the City of Tshwane. One of the proposed methods is the provision of economic incentives to the private sector. In this regard, the White Paper produced by the South African Department of Environmental Affairs (2015) encourages the general public to invest in local technologies that could be used for the efficient management of solid waste by local governments and municipalities. Some of the methods proposed by South African researchers include the commercialization of solid waste (Worku, 2013), forging strategic partnerships between the public and private sector (Seeletse, 2012), the effective implementation of municipal bylaws and legislative codes (Snyman \& Vorster, 2011), the use of appropriate local technology (LEAP (PTY) Ltd, 2011), and techniques that are based on decomposition of waste accumulated in landfills used by municipalities (Worku, Snyman \& Muchie, 2014). Public awareness campaigns and the provision of health education on personal hygiene and environmental sanitation have been used in developing cities such as Nigeria in accordance with guidelines set out by the United Nations Environmental Protection Agency (2015). The study conducted by Worku, Snyman and Muchie (2014) has pointed out that the current state of efficiency in the management of solid waste in Pretoria is grossly inadequate by international standards. The authors have pointed out that landfills are used as a predominant method of waste disposal in Pretoria, and that there is a dire need for utilizing modern technologies of waste disposal and processing. Examples of modern technologies that are appropriate for the efficient management of solid waste in the city of Pretoria have been pointed out by Dijkgraaf and Gradus (2004). Landfills are used extensively by the City of Tshwane for dumping municipal solid waste, and these landfills are not managed by using suitable and appropriate technology according to the research work conducted by Snyman and Vorster (2011). The study conducted by LEAP (PTY) Ltd (2011) has shown that the effective implementation of municipal bylaws and legislative codes issued by the South African Department of Environmental Affairs and Tourism is critical for an essential requirement for ensuring efficiency in the management of waste in the major metropolitan cities in South Africa including Pretoria.

\section{Objectives of study}

The aim of study was to identify and quantify factors that affect overall efficiency in the 
management of municipal solid waste generated by businesses that operate in Tshwane municipalities. The specific aims of the study were to assess the current state of solid waste management with regards to type of wastes and quantities of waste generated, to identify key factors that affect efficiency in the management of solid waste, and to assess the degree to which businesses adhere to norms and standards that are recommended for businesses in terms of solid waste disposal.

\section{Methods and materials of study}

The design of study was descriptive and crosssectional. Data were collected from a random sample of 1,035 businesses operating in Tshwane municipalities. Efficiency in the management of municipal solid waste was assessed by using a structural time-based model constructed by Tchobanoglous, Theisen and Vigil (1993), as well as the degree of adherence to municipal bylaws on proper waste management, as defined by the Canadian Standards Association (1999). Cross-tab analyses (Hair, Black, Babin \& Anderson, 2010), logit analysis (Hosmer \& Lemeshow, 2013) and multilevel analysis (Heck \& Thomas, 2015) were used for performing statistical data analyses. The statistical package STATA version 14 (2015) was used for performing data analyses.

\section{Results of study}

Table 1 in appendix shows a comparison between businesses that were efficient with regards to solid waste management with those that were not. It can be seen from the table that 857 of the 1,035 businesses $(82.88 \%)$ were efficient, while the remaining 178 businesses (17.12\%) were inefficient.

The table shows that a significant percentage of businesses located in the central and western parts of the city were inefficient, whereas businesses located in the eastern and northern parts of the city were by and large efficient. The table shows that about $83 \%$ of operators who managed businesses that were efficient with regards to waste management have acquired formal education at college level or better. In general, businesses that are inefficient in the management of waste are relatively younger, poor in personal hygiene and cleanliness of premises, and are by and large commercial. The majority of old businesses $(6$ years or more) are efficient in waste management. Businesses that are operated by owners are more efficient in comparison with businesses that are operated by employed managers. Utilization of private contractors for waste removal and management, regular inspection of premises by municipal workers, familiarity with the South
African White Paper on waste management, source reduction of waste, good perception on the benefits of proper waste management, and adherence to waste management regulations recommended by the municipality are much more common among businesses that are efficient in waste management.

Table 1 shows a list of 10 factors that were significantly associated with efficiency in the management of muncipal solid waste at business premises.

Table 1. Significant associations $(\mathrm{n}=1118)$

\begin{tabular}{|l|c|c|}
\hline \multicolumn{1}{|c|}{$\begin{array}{l}\text { Factors associated with efficiency in } \\
\text { municipal solid waste management }\end{array}$} & $\begin{array}{c}\text { Observed chi- } \\
\text { square value }\end{array}$ & P-value \\
\hline $\begin{array}{l}\text { Degree of adherence to waste } \\
\text { management regulations }\end{array}$ & 716.04 & 0.0000 \\
\hline $\begin{array}{l}\text { Positive perception on the benefits of } \\
\text { proper waste management }\end{array}$ & 705.99 & 0.0000 \\
\hline $\begin{array}{l}\text { Providing waste disposal bins to } \\
\text { customers }\end{array}$ & 701.42 & 0.0000 \\
\hline $\begin{array}{l}\text { The management of businesses by } \\
\text { actual owners }\end{array}$ & 469.21 & 0.0000 \\
\hline $\begin{array}{l}\text { Frequency of inspection of business } \\
\text { premises }\end{array}$ & 299.57 & 0.0000 \\
\hline Keeping personal hygiene of employees & 251.72 & 0.0000 \\
\hline $\begin{array}{l}\text { Degree of maintenance of waste } \\
\text { disposal bins and business premises }\end{array}$ & 167.09 & 0.0000 \\
\hline $\begin{array}{l}\text { Degree of cleanliness of business } \\
\text { premises }\end{array}$ & 139.88 & 0.0000 \\
\hline Level of education of business operator & 127.52 & 0.0000 \\
\hline $\begin{array}{l}\text { Regular inspection of premises by } \\
\text { municipal workers }\end{array}$ & 115.14 & 0.0000 \\
\hline
\end{tabular}

It can be seen from the table that the top 5 significant variables were: lack of adherence to municipal bylaws and regulations, wrong perception on the potential benefits of proper waste management, failure of businesses to provide customers with waste disposal bins, the status of the business operator (owner or employee), and the frequency at which business premises are inspected by municipal sanitation and health workers, in a decreasing order of strength.

Table 2 below shows results estimated from logit analysis (Hosmer \& Lemeshow, 2013) in which odds ratios are used as a measure of effect. The results show that efficiency in the proper management of municipal solid waste was significantly influenced by 3 predictor variables. These 3 influential predictor variables were lack of adherence to municipal bylaws and regulations $[\mathrm{OR}=9.17 ; 95 \%$ C. $\mathrm{I} .=(6.42$, 12.54)], wrong perception on the benefits of proper waste management $[\mathrm{OR}=8.81 ; 95 \% \mathrm{C}$. I. $=(6.01,11.35)]$, and failure to provide customers with waste disposal bins $[\mathrm{OR}=3.15 ; 95 \% \mathrm{C}$. I. = $(1.46,5.87)]$, in a decreasing order of importance. 
Table 2. Odds ratios estimated from logit analysis $(\mathrm{n}=1035)$

\begin{tabular}{|l|c|c|c|}
\hline $\begin{array}{c}\text { Factor that undermine efficiency in } \\
\text { municipal solid waste management }\end{array}$ & $\begin{array}{c}\text { Odds } \\
\text { ratio }\end{array}$ & $\begin{array}{c}\text { P- } \\
\text { value }\end{array}$ & $\begin{array}{c}95 \% \text { confidence } \\
\text { interval }\end{array}$ \\
\hline Poor adherence to municipal bylaws & 9.18 & 0.000 & $(6.42,12.54)$ \\
\hline $\begin{array}{l}\text { Wrong perception on benefits of } \\
\text { proper waste management }\end{array}$ & 8.84 & 0.000 & $(6.01,11.35)$ \\
\hline $\begin{array}{l}\text { Failure to provide customers with } \\
\text { enough waste disposal bins }\end{array}$ & 3.17 & 0.000 & $(1.46,5.87)$ \\
\hline
\end{tabular}

Results obtained from multilevel analysis (Heck \& Thomas, 2015) showed that there were significant differences among the 7 categories of waste in the study. The results showed that $23.05 \%$ of the total variation in efficiency is due to differences among the 7 categories of waste produced by business enterprises operating in the City of Tshwane. The results also showed that businesses within the same category of waste and geographical location were equally efficient in the management of solid waste.

\section{Discussion of results of study}

The study has shown that a combination of technical and administrative solutions is helpful for improving the current degree of efficiency in the management of municipal solid waste in Tshwane. Awareness campaigns and socioeconomic incentives could be provided by civic society and non-governmental organizations that have a vested interest in improving environmental sanitation and cleanliness. The City of Tshwane needs to make the necessary initial investment available in order to benefit from composting in the longrun. Extensive waste management research conducted in various parts of the world has shown that educating rural, as well as urban people on how to produce compost by using low technology has longterm economic benefits to big metropolitan municipalities such as Tshwane. Large scale compost activities require massive infrastructural investment and skills based training. The collection and recycling of plastic waste is characterized by serious challenges and difficulties in the City of Tshwane (Khale, 2015). The City of Tshwane has no coherent policy on the collection of e-waste. A well-functioning integrated solid waste management system can only be realized in the City of Tshwane by providing clear incentives for good practice and behavior, and by severely penalizing irresponsible behavior in the city. Worku, Snyman and Muchie (2014) have found that the provision of direct socioeconomic incentives, clear guidelines on the collection, disposal and processing of e and plastic waste, as well as a strict enforcement of municipal bylaws is required for improving overall efficiency in the management of e and plastic waste in the City of Tshwane.

Increasing general awareness about the benefits of proper waste disposal is a key requirement for success. The number of waste disposal sites is limited, and the disposal of waste is expensive. Since there are not enough of these facilities, hazardous waste is often transported over long distances, resulting in increased risks of accidents and higher transport costs. Some other helpful steps are to undertake an integrated plan in which waste is gathered and disposed of efficiently based on mutual collaboration among stakeholders. Strengthening the technical, financial, administrative and operating capacity of the institutions in the basic environmental sanitation sector, encouraging health education and community promotion activities, which are basic to the success of waste collection and disposal, especially at taxi ranks and the streets at the central business district of Pretoria, to provide clear incentives to businesses that improve the quality of waste collection and disposal based on generally accepted standards. Technical cooperation among stakeholders must be directed toward the strengthening of institutions in the basic environmental sanitation sector and emphasis should be given to the following activities: operation and maintenance, community promotion, training, administration and management, the preparation of plans and studies helpful for efficient waste disposal, and the application of technologies that are helpful for efficient waste disposal.

\section{Conclusion and recommendations}

The study showed that $17.12 \%$ of the 1,035 businesses in the study were not efficient enough with regards to the proper collection, disposal and management of solid waste. The study has shown that efficiency in the management of solid waste is adversely affected by lack of adherence to municipal bylaws and regulations on proper waste management, wrong perception on the potential benefits of proper waste disposal, failure to provide customers with enough trash cans at business premises, and the operation of businesses by employed managers, in a decreasing order of importance. Lack of adherence to municipal bylaws and regulations that are essential for proper waste management constitutes a key challenge in the City of Tshwane. The presence of wrong perception on the potential benefits of waste disposal is also a well known hurdle. To rectify this issue, a combination of three interventions is necessary. The first intervention is to enforce municipal bylaws with vigor. The second intervention is to provide incentives to businesses that manage solid waste properly in accordance with guidelines provided by the City of Tshwane. Regulatory and legislative actions must be taken against those who fail to 
respect municipal bylaws that are related to cleanliness and proper waste management. The efficient disposal of waste generated by businesses operating in the city has direct economic benefits to all inhabitants of the city. Accordingly, waste should be gathered efficiently, and disposed of in accordance with the waste collection and management plan produced by the City of Tshwane. Management of waste must start at the lowest level. The third intervention is to actively promote an education campaign in all parts of the City of Tshwane with a view to ensure the full collaboration of businesses conducting business in the City.

In light of findings obtained from the study, it is recommended that the City of Tshwane implements an integrated municipal solid waste management plan in collaboration with the relevant stakeholders in the city so that each of the role players in the waste management chain can investment adequately in basic environmental sanitation. It is also recommended that the City of Tshwane provide an incentive to the private sector as a means of improving overall efficiency in the management of municipal solid waste. It is beneficial to increase awareness about the potential benefits of proper waste collection and disposal by promoting health education on environmental sanitation and techniques that are useful for collecting and sorting waste.

\section{References}

1. Asah, F., Fatoki, O.O. \& Rungani, E. (2015). The impact of motivations, personal values and management skills on the performance of SMEs in South Africa, African Journal of Economic and Management Studies, 6(3), pp. 308-322.

2. Bernstad, A., Jansen, J. \& Aspegren, H. (2012). Local strategies for efficient management of solid household waste - the full-scale Augustenborg experiment, Waste Management \& Research, 30(2), pp. 200-212.

3. Brownson, C.D. (2014). Does constituent of entrepreneurial culture differ in individuals? International Journal of Small Business and Entrepreneurship Research, 2(2), pp. 22-27.

4. Canadian Standards Association (1999). ISO 14031 and ISO 14032 Guidelines. Toronto: Canadian Standards Association.

5. City of Tshwane Metropolitan Municipality (CTMM) (2015). Annual report for 2013/2014. Available from: www.tshwane.gov.za.

6. Dijkgraaf, E. \& Gradus, R.H.J.M. (2004). Cost savings in unit-based pricing of household waste: The case of The Netherlands, Resource and Energy Economics, 26(4), pp. 353-371.

7. Edoho, F.M. (2015). Entrepreneurialism: Africa in transition, African Journal of Economic and Management Studies, 6(2), pp. 127-147.

8. Hair, J.F., Black, W.C., Babin, B.J. \& Anderson, R.E. (2010). Multivariate Data Analysis: A Global Perspective. London: Pearson.

9. Heck, R.H. \& Thomas, S.L. (2015). An Introduction to Multilevel Modelling Techniques: MLM and SEM Approaches Using Mplus. New York: Routledge.

10. Henrekson, M. (2014). Entrepreneurship, innovation, and human flourishing, Small Business Economics, 43(3), pp. 511-528.

11. Hosmer, D.W. \& Lemeshow, S. (2013). Applied Logistic Regression Analysis. New York: John Wiley \& Sons.

12. Khale, S. (2015). Assessment of the quality of municipal services in the City of Tshwane, South Africa. Journal of Corporate Ownership and Control, 13(1), pp. 678-695.

13. LEAP (PTY) Ltd. (2011). Utilization of reproductive health services among women 15 to 49 years of age at the City of Tshwane Metropolitan Municipality: A research report prepared for the City of Tshwane Metropolitan Municipality. Pretoria: LEAP (PTY) Ltd.

14. Marivate, S.P. (2014). The impact of entrepreneurial skills on the viability and long-term survival of small businesses: a case of the city of Tshwane, South Africa, European Journal of Business, Economics and Accountancy, 2(2), pp. 53-72.

15. Seeletse, S.M. (2012). Common causes of small businesses failure in the townships of West Rand district municipality in the Gauteng Province of South Africa, African Journal of Business Management, 6(44), pp. 10994-11002.

16. Shree, S. \& Urban, B. (2012). Internationalisation of South African SMEs: The role of capital factors, Acta Commercii, 12(1), pp. 186-199.

17. Snyman, J. \& Vorster, K. (2011). Sustainability of composting as an alternative waste management option for developing countries: a case study of the City of Tshwane, Waste Management \& Research, 29(1), pp. 1222-1231.

18. South African Chamber of Commerce and Industry. (2016). Business confidence index - Press release. Available from: http://www.sacci.org.za/

19. South African Small Enterprise Development Agency (SEDA) (2013). SAIE learning loop: Why the loop? Available from: http://www.entrepreneurship.co.za/

20. South African National Department of Environmental Affairs. (2015). Annual report for 2013/2014. Available from: https://www.environment.gov.za/

21. Stata Corporation (2015). User's Guide for STATA version 14. College Station, Texas, USA: Stata Corporation.

22. Statistics South Africa (2015). Income and expenditure survey 2013/2014. Available from: http://www.statssa.gov.za/ies/welcome.asp. 
23. Tchobanoglous, G., Theisen, H. \& Vigil, S.A. (1993). Integrated solid waste management Engineering Principles and Management Issues. New York: McGraw Hill.

24. United States Environmental Protection Agency (2015). Municipal Solid Waste in the United States: Facts and Figures. Available from: http://www.epa.gov/msw/facts.htm.

25. Wagland, S.T., Veltre, F. \& Longhurst, P.J. (2012). Development of an image-based analysis method to determine the physical composition of a mixed waste material, Waste Management, 32(2), pp. 245-248.

26. Worku, Y., Snyman, J. \& Muchie, M. (2014). The management of municipal solid waste generated by businesses operating in the city of Tshwane, South Africa, European Journal of Engineering and Technology, 2(2), pp. 77-106.

27. Worku, Y. (2013). Differential factors of solid waste management in Pretoria. Berlin: Lambert Academic Publishers.

28. Worku, Z. (2014). Differential factors of long-term survival in small and medium-sized business enterprises in Pretoria, South Africa, Journal of Business and Economics, 5(11), pp. 2091-2104. 


\section{Appendix}

Table 1. Comparison of businesses $(n=1,035)$

\begin{tabular}{|c|c|c|}
\hline Characteristic & Efficient $(\mathrm{N}=857)$ & Inefficient ( $N=178)$ \\
\hline Category of business & $\begin{array}{c}\text { Agricultural: } 1 \% \\
\text { Commercial: } 71 \% \\
\text { Construction: } 6 \% \\
\text { Industrial: } 11 \% \\
\text { Institutional: } 2 \% \\
\text { Municipal: } 6 \% \\
\text { Manufacturing: } 3 \%\end{array}$ & $\begin{array}{c}\text { Agricultural: } 1 \% \\
\text { Commercial: } 83 \% \\
\text { Construction: } 3 \% \\
\text { Industrial: } 3 \% \\
\text { Institutional: } 3 \% \\
\text { Municipal: } 5 \% \\
\text { Manufacturing: } 2 \%\end{array}$ \\
\hline $\begin{array}{l}\text { Geographical location of business in the City } \\
\text { of Tshwane }\end{array}$ & $\begin{array}{l}\text { Central: } 31 \% \\
\text { East: } 21 \% \\
\text { West: } 19 \% \\
\text { North: } 17 \% \\
\text { South: } 12 \%\end{array}$ & $\begin{array}{l}\text { Central: } 41 \% \\
\text { East: } 13 \% \\
\text { West: } 23 \% \\
\text { North: } 13 \% \\
\text { South: } 10 \%\end{array}$ \\
\hline Age of business in years & $\begin{array}{l}\text { Less than a year: } 5 \% \\
1 \text { to } 2 \text { years: } 6 \% \\
3 \text { to } 5 \text { years: } 29 \% \\
6 \text { years or more: } 60 \%\end{array}$ & $\begin{array}{l}\text { Less than a year: } 34 \% \\
1 \text { to } 2 \text { years: } 35 \% \\
3 \text { to } 5 \text { years: } 15 \% \\
6 \text { years or more: } 16 \%\end{array}$ \\
\hline Status of business operator & $\begin{array}{l}\text { Owner: } 76 \% \\
\text { Manager: } 24 \%\end{array}$ & $\begin{array}{l}\text { Owner: } 31 \% \\
\text { Manager: } 69 \%\end{array}$ \\
\hline Level of education of operator & $\begin{array}{l}\text { College level or better: } 76 \% \\
\text { High school level or less: } 24 \%\end{array}$ & $\begin{array}{l}\text { College level or better: } 39 \% \\
\text { High school level or less: } 61 \%\end{array}$ \\
\hline Gender of operator & $\begin{array}{l}\text { Male: } 76 \% \\
\text { Female: } 24 \%\end{array}$ & $\begin{array}{l}\text { Male: } 73 \% \\
\text { Female: } 27 \%\end{array}$ \\
\hline $\begin{array}{l}\text { Use of private contractor for waste } \\
\text { management }\end{array}$ & $\begin{array}{l}\text { Yes: } 23 \% \\
\text { No: } 77 \%\end{array}$ & $\begin{array}{l}\text { Yes: } 16 \% \\
\text { No: } 84 \%\end{array}$ \\
\hline Sorting waste & $\begin{array}{l}\text { Yes: } 76 \% \\
\text { No: } 24 \%\end{array}$ & $\begin{array}{l}\text { Yes: } 45 \% \\
\text { No: } 55 \%\end{array}$ \\
\hline Adherence to waste management regulations & $\begin{array}{l}\text { Yes: } 95 \% \\
\text { No: } 5 \%\end{array}$ & $\begin{array}{l}\text { Yes: } 52 \% \\
\text { No: } 48 \%\end{array}$ \\
\hline Personal hygiene & $\begin{array}{c}\text { Excellent: } 9 \% \\
\text { Very good: } 43 \% \\
\text { Satisfactory: } 37 \% \\
\text { Less than satisfactory: } 10 \% \\
\text { Poor: } 1 \%\end{array}$ & $\begin{array}{c}\text { Excellent: } 0 \% \\
\text { Very good: } 21 \% \\
\text { Satisfactory: } 41 \% \\
\text { Less than satisfactory: } 33 \% \\
\text { Poor: } 5 \%\end{array}$ \\
\hline $\begin{array}{l}\text { Perception on the benefits of proper waste } \\
\text { management }\end{array}$ & $\begin{array}{c}\text { Excellent: } 3 \% \\
\text { Very good: } 56 \% \\
\text { Satisfactory: } 35 \% \\
\text { Less than satisfactory: } 5 \% \\
\text { Poor: } 1 \%\end{array}$ & $\begin{array}{c}\text { Excellent: } 1 \% \\
\text { Very good: } 6 \% \\
\text { Satisfactory: } 29 \% \\
\text { Less than satisfactory: } 55 \% \\
\text { Poor: } 9 \%\end{array}$ \\
\hline Source reduction of waste & $\begin{array}{l}\text { Yes: } 80 \% \\
\text { No: } 20 \% \\
\end{array}$ & $\begin{array}{l}\text { Yes: } 52 \% \\
\text { No: } 48 \% \\
\end{array}$ \\
\hline $\begin{array}{l}\text { Amount of waste generated in } 1,000 \mathrm{~kg} \text { per } \\
\text { week }\end{array}$ & $\begin{array}{l}\leq 0.9: 25 \% \\
1 \text { to } 1.9: 46 \% \\
2 \text { to } 4.9: 27 \% \\
5 \text { to } 9.9: 2 \% \\
\geq 10: 0 \%\end{array}$ & $\begin{array}{l}\leq 0.9: 49 \% \\
1 \text { to } 1.9: 42 \% \\
2 \text { to } 4.9: 8 \% \\
5 \text { to } 9.9: 1 \% \\
\geq 10: 0 \%\end{array}$ \\
\hline Enough trash cans available for customers & $\begin{array}{l}\text { Yes: } 77 \% \\
\text { No: } 23 \%\end{array}$ & $\begin{array}{l}\text { Yes: } 46 \% \\
\text { No: } 54 \%\end{array}$ \\
\hline $\begin{array}{l}\text { Regular inspection of premises by } \\
\text { municipality }\end{array}$ & $\begin{array}{l}\text { Yes: } 84 \% \\
\text { No: } 16 \% \\
\end{array}$ & $\begin{array}{l}\text { Yes: } 41 \% \\
\text { No: } 59 \% \\
\end{array}$ \\
\hline $\begin{array}{l}\text { Familiarity of operator with White Paper on } \\
\text { Waste Management }\end{array}$ & $\begin{array}{l}\text { Yes: } 86 \% \\
\text { No: } 14 \%\end{array}$ & $\begin{array}{l}\text { Yes: } 28 \% \\
\text { No: } 72 \%\end{array}$ \\
\hline
\end{tabular}

